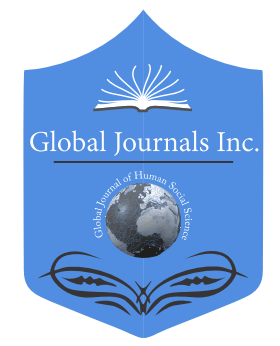

\title{
Using Culturally and Linguistic Responsive and Translanguaging Pedagogy to Teach Science
}

\author{
By Yu Ren Dong \\ City University of New York
}

Introduction- More and more students in today's secondary subject matter classrooms in America are bilingual ELLs (English language learners), a fast-growing student population in the U.S. public schools (National Center for Education Statistics, 2019). In New York City, about 50\% of the total public-school students speak a language other than English at home and one out of every six secondary school students are an ELL (New York City Department of Education, 2019). Those ELLs are served by the three language programs: TBE (Transitional Bilingual Education program, mostly for middle and high school students), DL (Dual Language Program, mostly for elementary and middle school students), ENL (English as a new language program, formerly ESL, for almost all ELLs). In this article, I focus on bilingual subject matter instruction for high school students in the TBE program. Every day, the secondary ELLs in the TBE program attend subject matter classes taught by bilingual subject matter teachers using the bilingual education pedagogy. According to the guidelines shown on the website of New York City Department of Education:

The Transitional Bilingual Education program provides reading, writing, and other classes in English and in the student's home language. As students' English improves, more time is spent learning in English and less time is spent learning in their home language. The goal of a TBE program is to support students in their home language while they fully transition to an English-only instruction class.

GJHSS-G Classification: FOR Code: 200399

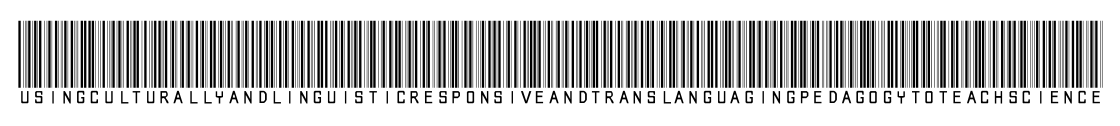

Strictly as per the compliance and regulations of:

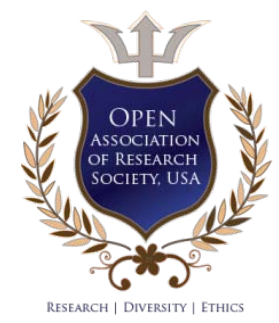

(c) 2021. Yu Ren Dong. This research/review article is distributed under the terms of the Attribution-NonCommercial-NoDerivatives 4.0 International (CC BY-NC-ND 4.0). You must give appropriate credit to authors and reference this article if parts of the article are reproduced in any manner. Applicable licensing terms are at https://creativecommons.org/licenses/by-nc-nd/4.0/. 


\title{
Using Culturally and Linguistic Responsive and Translanguaging Pedagogy to Teach Science
}

\author{
Yu Ren Dong
}

\section{InTRODUCTION}

M ore and more students in today's secondary subject matter classrooms in America are bilingual ELLs (English language learners), a fast-growing student population in the U.S. public schools (National Center for Education Statistics, 2019). In New York City, about $50 \%$ of the total public-school students speak a language other than English at home and one out of every six secondary school students are an ELL (New York City Department of Education, 2019). Those ELLs are served by the three language programs: TBE (Transitional Bilingual Education program, mostly for middle and high school students), DL (Dual Language Program, mostly for elementary and middle school students), ENL (English as a new language program, formerly ESL, for almost all ELLs). In this article, I focus on bilingual subject matter instruction for high school students in the TBE program. Every day, the secondary ELLs in the TBE program attend subject matter classes taught by bilingual subject matter teachers using the bilingual education pedagogy. According to the guidelines shown on the website of New York City Department of Education:

The Transitional Bilingual Education program provides reading, writing, and other classes in English and in the student's home language. As students' English improves, more time is spent learning in English and less time is spent learning in their home language. The goal of a TBE program is to support students in their home language while they fully transition to an English-only instruction class. Classes are made up of students with the same home language. (New York City Department of Education, 2021)

Clearly, the TBE pedagogy is rooted in the monolingual ideology and views bilingual students' $\mathrm{L} 1$ as a temporary support for them to learn English. The bilingual subject matter teacher is given the guidelines of using $80 \%$ of their students' $L 1$ in the beginning of the year/semester and reducing the L1 use to $20 \%$ or less by the end of the year/semester. The bilingual ELLs' L1 support will be gradually removed over time once they can communicate in English. This approach to bilingual education becomes problematic when about two-thirds

Author: Professor of secondary education at Queens College, City University of New York, U.S.A. She teaches secondary school teacher education courses, and her research areas include preparing mainstream subject area teachers for English language learners and preparing secondary bilingual teachers to teach biliteracy in their subject matter classes.e-mail: yu.dong@qc.cuny.edu of the secondary bilingual ELLs in New York City have received either equivalent or close to equivalent subject matter education before coming to the U.S. in their home countries. However, their lack of English language proficiency and the TBE program set up prevents them from a fast transition in their subject matter learning to meet the graduation standards.

A recent count of the graduation rate (New York State Department of Education 2018-2019) for New York City English proficient students was $81 \%$, while only $41 \%$ of ELLS graduated. When comparing the pass rate on the Regents exams (a measure in graduation standards), while $70 \%$ of English-proficient high school students passed the regent's exam in living sciences (biology), only $35 \%$ of ELLs did so. Although, ELLs have an option of using the alternative language edition translated into Spanish, Chinese, Korean, Haitian Creole, Russian and write their responses to the openended questions in their native language on the Regents exam, this option was not fully utilized due to the English only goal and set up of the TBE program. The TBE program approach and structure limits the use of students' native languages and the artificial design of alternations or percentages between the use of English and students' native languages is not effective and even detrimental to bilingual ELLs' language and subject matter knowledge development. All this points to the urgent need to re-examine the bilingual education pedagogy for secondary bilingual ELLs.

Recent research in bilingual education has called attention towards re-examining the traditional bilingual education program, such as TBE and monolingual approach to bilingual education. Most research in the US initiated by Garcia on the potentials and benefits of the Translanguaging pedagogy has expanded our views on what bilingual and biliteracy education is all about. Translanguaging pedagogy argues for drawing on and intermingling emergent bilingual students' full linguistic repertoire-all languages and literacy skills to promote those students' bilingual and biliteracy development (Aguilar, et al., 2020; Garcia and Wei, 2014; Sharon, et al., 2021). By incorporating various language forms, skills, and competences purposefully, systematically bilingual students have multiple accesses to and develop ways of learning, interacting, and practicing their bilingual and biliteracy and subject matter knowledge and skills. Therefore, it's the purpose of this article to explore the benefits and 
ways of using the culturally relevant and Translanguaging bilingual education pedagogy in a secondary Chinese bilingual biology class.

\section{Literature ReVIEW}

\section{a) Science Instruction for Linguistically and Culturally Diverse Students}

Over the years, the changing student body in science classrooms has prompted investigations into using culturally relevant pedagogy to effectively serve the ELLs in science education (Cho and McDonnough, 2009; Lee and Fradd, 2001). The culturally relevant teaching pedagogy originally focused on educational disparities of racial minority students in the 1990s. (Gay, 2010; Ladson-Billings, 1995) and delineated three major teaching applications to address these disparities by

1. Teachers' investigation of students' prior knowledge;

2. Teachers' recognition and inclusion of students' prior knowledge and voices in their curriculum and instruction; and

3. Teachers' adjustment made during the teaching process to engage and motivate students to participate in the learning process (Ladson-Billings, 1995).

Later with a tremendous increase of ELLs in American classrooms, the linguistically responsive pedagogy complemented and expanded the culturally relevant science teaching pedagogy to take into account bilingual/ELL students' native languages, literacy backgrounds obtained in their native country, culturally familiar examples, and previous science learning experiences in ESL education (Dong, 2014, 2017; Lucas \& Villegas, 2013; Rupley and Slough, 2010; Rosebery and Warren, 2008; Short, et al., 2011). Research has shown that when using linguistically and culturally responsive approach to teach science, students respond positively and engage actively in the learning process (Lee, et al. 2007; Lucas and Villegas, 2013). Also, instead of teaching science or scientific language separately, research findings have shown the benefit of engaging bilingual students' two languages in learning science and teaching both science knowledge and language together to achieve their development in scientific knowledge and skills as well as in their bilingual language skills (Amaral, et al., 2002; Bialystok, 2008; Meyers and Crawford, 2011; Moore and Schleppegrell, 2020; Morrison, et al., 2020).

\section{b) Translanguaging Pedagogy in Bilingual Science Instruction}

Most recently, bilingual education research pointed out the problems and limitations of the existing bilingual education models and pedagogy. Derived from this line of research is the arrival of Translanguaging pedagogy to argue for the positive effect of teachers' systematic, active, and purposeful activation and mobilization of bilingual students' full linguistic repertoire cross language boundaries in bilingual science classrooms to increase bilingual/ELLs participation, understanding, and discussion of the language and subject matter topic under study.

Cummins' Linguistic Independence theory provides the foundation of Translanguaging pedagogy. According to Cummins (1979), there is a strong underlying connection in language proficiency between languages at the deeper level of reading, writing, and oral language. Also, there is a conceptual knowledge base shared between languages at the CALP level. In other words, bilingual students' native language and cognitive competence and skills gained in their schooling in L1 can be transferred into the understanding of $\mathrm{L} 2$ at the deeper cognition and academic language level. Thus, what ESLs bring to the classroom should be used to learn not only the surface level L2, such as spelling and pronunciation but also the deep level of concepts, such as metaphorical ways of thinking and doing science. For Cummins "language and content will be acquired most successfully when students are challenged cognitively but provided with the contextual and linguistic supports or scaffolds required for successful task completion" (Cummins, 2000 , p. 71). For secondary bilingual students who have had either equivalent or some subject matter knowledge and skills in the subject matter topic under instruction, Translanguaging pedagogy has an important role to play in moving beyond word-for-word concept translations to fully using students' linguistic repertoire and developing bilingual students' biliteracy skills (Garcia, et al. 2017; Garicia and Kleyn, 2016). Beeman and Urow (2013) argued that bilingual students' cognitive and linguistic assets, including their previous learning history and native language and literacy skills must be recognized and used in teaching subject matter knowledge and language.

Even though Cummins' theory has become the guiding principle for both the ESL and bilingual education, there is still a gap between research and practice. Under the pressure of the standardized tests and graduation demands and restrictions from the TBE program guidelines, bilingual science education practice has yet to implement the research findings. Rather, secondary bilingual science education still operates from the monolingual model and uses separate or sequential bilingual education approaches. Often the bilingual science teachers are settling for using the word-for-word translation method to teach bilingual science and using the surface word level discussions (Hornberger and Link, 2012; Lee, et al. 2007; Licona and Kelly, 2020, Unsal, et al., 2018). Due to the limited and sporadic and surface level use of students' L1, bilingual/ELLs cannot access and gain an accurate and in-depth concept understanding or 
participate in an inquiry-discussion about the concept in an extended and in-depth manner. All this is especially problematic when conceptual understanding is the goal of science education and using language to do inquirybased science discussion is the hallmark of science instruction. Therefore, it's important to prepare for using culturally and linguistical responsive Translanguaging pedagogy. The research questions were:

\section{ili. Research Questions}

What prior knowledge that secondary bilingual ELLs brought into the science classroom?

What bilingual science teachers did to use culturally and linguistically responsive and Translanguaging pedagogy to teach science to bilingual ELLs?

\section{Research Context}

In the 2018-2019 academic year, I worked with 15 certified subject matter teachers who were seeking New York State bilingual extensions. Their subject matter areas ranged from mathematics to social studies to science. In this article, I focus on Mike (pseudonym), a high school biology teacher who had been teaching biology to bilingual/ELLs for seven years at the time of the study. Mike had both New York State science teaching certificate and a master's in science education. As a Chinese bilingual who originally came from Taiwan after completing middle school, Mike had an intimate knowledge about the Chinese education and culture. Growing up speaking both Chinese and later English, Mike was big on teaching his Chinese bilingual ELLs the importance of improving their native language while learning English. Mike's science Assistant Principal encouraged Mike to pursue a Chinese bilingual extension to better serve his students.

I had Mike as a student in my class entitled SEYS 745: Reading and Writing for Diverse Students in Subject Matter Classes, one of the five Secondary Bilingual Education courses that Mike was completing for his bilingual extension license. Mike reflected on his bilingual language learning like this:

I grew up in Taiwan where I solely spoke Chinese Mandarin. I developed a solid base in science and literacy in my first language. The Taiwanese public-school students started learning English when they begin their middle schools. So, I consider myself a sequential bilingual. Because of my strong foundation in Chinese language and subject matter education in my early years of schooling. I would transfer my Chinese skills to English. Now as a science teacher, I often find incidents where I can use what my students learned in China and Taiwan to make a reference or analogy to teach the concept under study to make abstract and challenging scientific concepts understandable for my Chinese bilingual students.

Mike was teaching in a multilingual and multicultural inner city public high school with over 3,500 students in Queens, New York City. Among 3,500 students, 602 or $17 \%$ were ELLs and close to half of the ELLs were Asian ELLs. The science department offers quite a few bilingual science classes, such as bilingual biology, chemistry, earth science, etc. in Chinese, Korean, Spanish, etc. At the time of the study, Mike was teaching two Chinese biology classes besides his three regular biology classes for English proficient students. Each of his classes had about 30 students. Having worked with his Chinese bilingual ELLs, Mike realized the need to pursue his Chinese bilingual extension to better serve these students. Using the Transitional Bilingual Education (TBE) program, Mike's science curriculum aimed to prepare its bilingual students for the New York Regents exams in life sciences.

In light of the recent research and reconceptualization of bilingual education, I placed the Translanguaging and culturally and linguistic responsive pedagogy front and center in the class readings, discussions, and assignments. Along with other students, Mike was asked to do a cross-cultural literacy education by doing the two readings selected in the scholarly journals about the culture and literacy education and interviewing three people who had had secondary education in the country whose people speak the same language that Mike was seeking in the bilingual extension. Near the end of the semester, students were required to apply translanguaging and culturally and linguistic responsive pedagogy to their subject matter teaching contexts by designing and teaching a series of bilingual subject matter lessons.

Data collected included Mike's semester long reflections, cross-cultural literacy study report, class discussions, bilingual biology lessons, and biliteracy teaching report, which included three lessons using the Translanguaging and culturally and linguistic responsive pedagogy.

\section{Results and Discussion}

Although New York City public schools have a systematic and formal approach to identifying and providing students' levels of English proficiency, there is no formal system set up to evaluate those ELLs' levels of native language and subject matter knowledge learned in their home countries. Teachers can only assess the students' previous school records and/or transcripts translated from another language into English.

To uncover their students' prior subject matter knowledge and native language literacy backgrounds, those inservice teachers studied the education system of a country whose people speak the language that they were seeking the bilingual teaching extension. Each student read two scholarly articles about the education system, curriculum, instruction, and assessment of the country, interviewed three cultural and educational 
insiders' who had had schooling up to $8^{\text {th }}$ grade in that country, and wrote about what they had learned. Below is a sample interview response from two of Mike's student interviewees:

Back in China, in middle school we learned physics first, then chemistry, and finally biology. Students are not required to pass the standardized test on it like the Regents exam here in the U.S.; instead, we are required to learn each subject for one year and complete all three subjects by the end of senior high school. However, we do have Gao $\mathrm{KaO}$, an annual college entrance exam for three days, where general science, such as biology, physics, and chemistry is tested and the scores were used for the college admission. By Ling, a $9^{\text {th }}$ grader.

I love science and read 100,000 whys (十万个为什么), a popular science book series in my spare time. The series covered many popular science topics. Each chapter opens up with a why question. It asks the reader to think about common problems in daily life and use scientific knowledge to solve it. For example, "Why does a bike have two wheels?" "Why does cement harden after contacting with water?" It then provides us with a detailed explanation and scientific reasoning behind it. I like to read those books because they tell me something that I don't know before. by Sam, a $10^{\text {th }}$ grader.

Findings obtained from Mike's cross-cultural literacy education study not only informed him of where his students came from but also intrigued and energized his students by their teacher's sincere interest in what they learned and knew. Mike's student interviewees talked and wrote about the differences between American education and Chinese education in two languages using both English and Chinese and revealed their struggles in the new culture and learning environment. Below is Qining's bilingual reflection:

Chinese Version:

来美国之前，听说美国上课很自由，课程很简单，考试 也不多。所以, 当我来到美国时, 我很期待上学。但是

开学的第一天, 我就震惊了。所有内容均为英文。记得 放学的第一天, 我默默地走回家的路上边走边走流下了 眼泪。回到家我不想吃饭, 回到家一句话也不想说, 直 接回房间去了。我一边哭一边翻译家庭作业和课堂笔记. 那天 -上我一直弄到凌晨2点。我在前三周重 - 了相同 的循 - 。沗太大了, 我真的很想回国。但三周后的一 天, 我通・了一次生物・ - , 那一刻, 我松了一口气。 在那之后, 我有了一点自信, - 然有 - 我 - 是想放弃, 但我一直・持到・在。

\section{English Version}

Before I came to the United States, I heard that the United States was free in class, the curriculums were very simple, and there were not many exams. So, when I came to the United States, I was looking forward to going to school. By the end of the first day of school, I was shocked. All the content was in English. I remembered the first day after school I walked home silently and shed tears on the way. When I got home, I didn't want to eat, I didn't want to say a word, I went straight to my room. I locked myself in the room, and I was crying and translating. I stayed awake until 2 AM. I repeated the same cycle for the first three weeks. The pressure was so great that I really wanted to go back home. But one day after three weeks I passed a biology quiz which at that moment, I feel relieved. After that, I feel a little bit more confident, although I still want to give up, I have been persisting until now. Qining, $9^{\text {th }}$ grader.

Inspired by his findings from the cross-cultural literacy education study and guided by the Translanguaging and culturally and linguistic responsive teaching principles, Mike designed his lessons differently by purposefully and explicitly using his students' biliteracy skills and their prior knowledge about biology in the class discussions. Mike's class talks focused on concept learning through inquiry-based discussions. With newly learned teaching pedagogy and knowledge about his students' prior learning, Mike would start the lesson by inviting students to question or comment on the topic by speaking in Chinese and/or English. This ritual helped Mike center the discussion around the student's questions or comments. Throughout the discussion, Mike would take his students on a journey to explore the challenging concepts and do a scientific inquiry. The following excerpt illustrates one of Mike's discussions about the gas exchange in humans:

Student 1: 邊讀文章一邊解註解, 讓我讀的數度變好慢喔 (English translation: while reading it slows down my speed of reading so much if I annotate the text.).

Teacher (Mike): Yes, indeed. Biology text reading is close reading. During the reading, you have to take a break to reflect.

Student 1: 那是我該怎麼開始? (English translation: But how do I begin?)

Teacher: You can start with the title. What do you think the text is all about by reading the title?

Student 2: 人体空氣交換 (English translation: gas exchange in humans)

Teacher: Good. Where do you think 人体空氣交換 or gas exchange takes place?

Student 3: 肺 (English translation: lung)

Teacher: What is the English for 肺

Student 4: Lungs

Teacher: Good. Where does gas exchange occur in the lungs?

Student 4: 那個有泡泡的東西 (English translation: the thing looks like bubbles)

Teacher: Yes, you are right. But what is the name for those bubbles?

Student 5: 肺泡 
Teacher: Excellent, in Chinese it means 肺泡 Let's think about what you have learned about all this back in China (gave students 5 minutes to think)

Student 6: I learned this 肺泡 in my biology class in China. I remember my biology teacher asking us to take a deep breath and saying that is when the 肺泡膨胀像气球使你吸收你呼进氧气 (English translation: you inhale to open up your lungs and expand your lungs, alveole is like a balloon),

Teacher: Excellent. I like the balloon analogy here. What other analogy can we use? Think about the functions of 肺泡 to inhale, to open up the air in the lungs, and to exhale to close down the air in the lungs. (gave students another 3 minutes to think) What happened when you inhale?

Student 7: We breathe in oxygen.

Teacher: What do those 肺泡 do?

Student 7: 肺泡打开使你吸收你呼进氧气 (English translation: it opens up to let you get oxygen)

Teacher: What happened when you exhale?

Student 6: Then the 肺泡湶释放你呼出的废物二氧化碳 (English translation: it closes to let you get out the carbon dioxide.)

Student 7: Then 肺泡 work like 丰满 new grapes and when we inhale, 肺泡 work like 葡萄干dry raisins when we exhale.

Teacher: Excellent. How do we put all this into English?

Student 7: We use 肺泡 to breathe in oxygen and breathe out carbon dioxide. But do we have only one 肺泡 in each lung?

Teacher: Excellent question. What do you think? What do you remember?

Student 6: My biology teacher told us there are many. I don't know how many.

Teacher: In each lung there are millions of 肺泡

Students: Wow! That many?

Teacher: Let's say the word together by following me: Alveolus, al-vee-uh-las

Class: al-vee-uh-las

Teacher: Good. As Chinese doesn't have plural forms for the nouns such as 肺泡 but you all have learned the English plural forms for nouns. If I say one 肺泡in English is alveolus. Can you guess what will be the plural form for alveolus?

Student 6: Alveoluses?

Teacher: What other words in biology we learned not long ago like this one ending with -lus?

Student 7: Like nucleus and nuclei?

Student 8: I know, I know. It's alveoli.

Teacher: Excellent! Now I want you to use what we just talked about to read and make notes of this excerpt on gas exchange. Make sure to use the reading comprehension strategies we learned.

In the above class discussion, Mike and students used both English and Chinese actively and freely to discuss the concept of gas exchange and its functions. Notice that student 1 started the conversation commenting on the difficulty with the reading. By Mike acknowledging that and using Chinese students' L1, students were willing and able to invest more in the discussion using both languages. Thus, there is a good coverage of student participation. In the middle of the discussion, a critical juncture of concept exploration, Mike explicitly asked students about what they knew about this topic in their schooling in China. Mike later revealed that the cross-cultural education study opened his eyes to learn that many of his students had already learned some of the biology concepts. So, before each unit he made it a habit of asking students for any knowledge they learned related to the topic under study.

Rather than quickly giving out a one-on-one translation of the word alveolus, Mike engaged his students in an analogical and conceptual exploration of what the alveolus does by drawing on their previous education and by generating analogies to express and further their understanding. Notice that when students used L1, they engaged more with the concept and pushed for scientific and analogical reasoning to deepen their understanding. Noteworthy is also students' genuine interest in the concept and willingness to move the discussion forward to analogical reasoning, such as comparing alveolus to a balloon and grape. Finally, trusting his students' linguistic and cognitive skills, Mike ended the discussion by asking students to make an intelligent guess about the plural form of alveolus.

Following the class discussion, Mike's students did a close reading about the gas exchange and created text notes about the reading. Below is Jane's reading notes on gas exchange. Throughout the semester, Mike taught students how to take notes in doing biology text reading. He encouraged students to use English as well as Chinese to demonstrate their understanding as well as their questions and confusions. Several note-making strategies were illustrated and practiced by the class over the semester. They are:

- Summarizing what you have read so far.

- Underlining new words in the reading.

- Using Chinese and/or scientific symbolic language to assist reading comprehension.

- Asking questions about the topic and what you don't know.

- Relating the old knowledge to the new.

Below is Jane's notes on her reading of the gas exchange in humans.

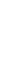

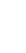


Within the alveoli, an exchange of gases takes place

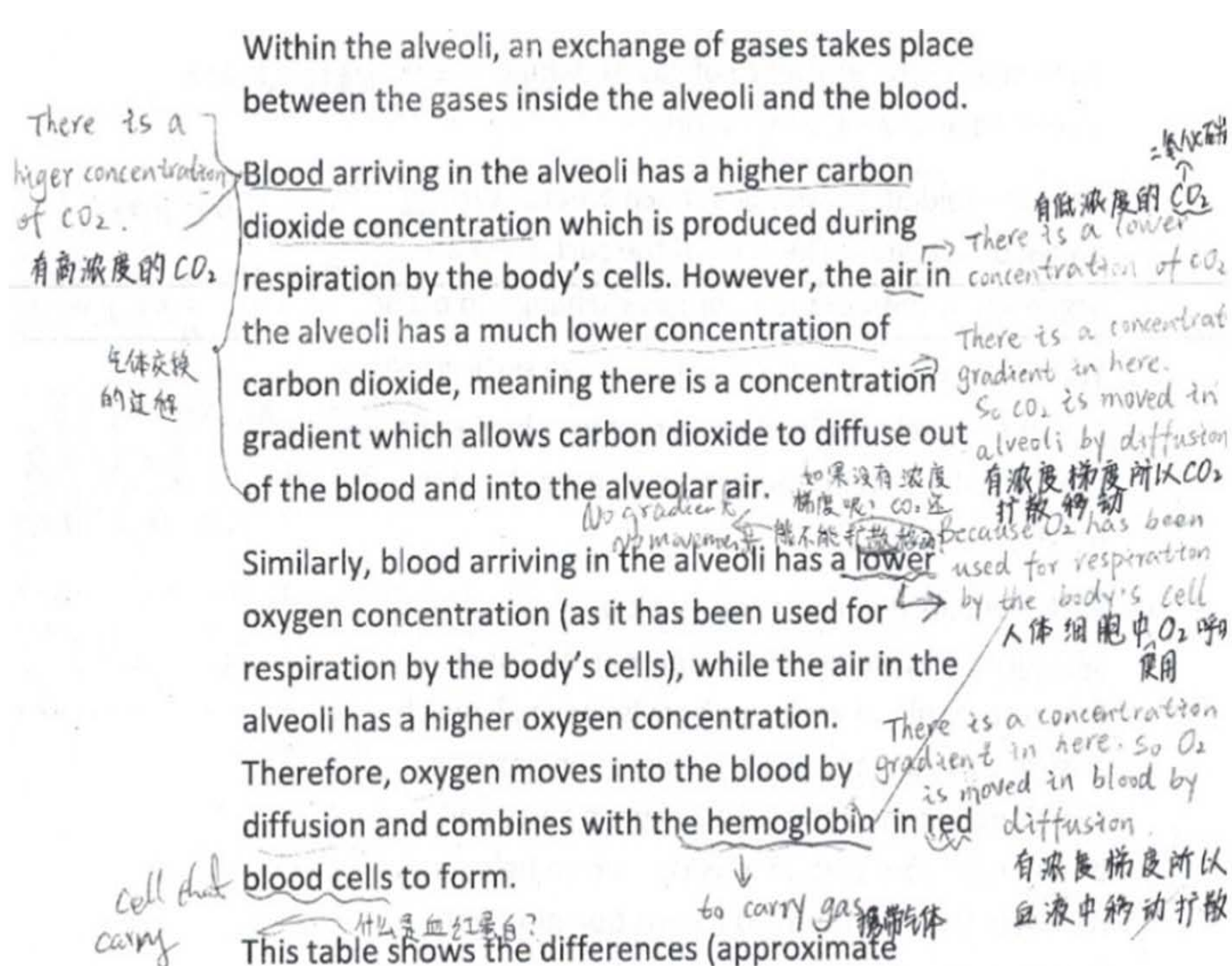

$\begin{aligned} \mathrm{O}_{2} & \text { figures) in the } \\ & \text { composition of } \\ & \text { inhaled and } \\ & \text { exhaled air. }\end{aligned}$

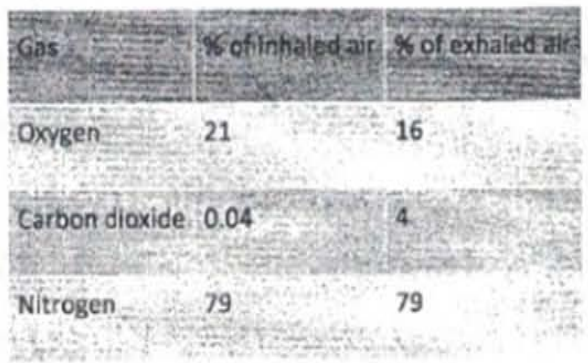

In the above reading notes, Jane, followed the note-taking guidelines taught and modeled by Mike to summarize what she wrote line by line on the margins of the text and underlined key words that proved to be critical for her understanding of gas exchange. In addition, Jane connected the alveoli function of giving out carbon dioxide to the concept of diffusion, which they learned before. A few Chinese words/sentences written on the margins provide interesting insights. A closer examination of those Chinese words/sentences showed Jane's questions, such as "What happens when there is no concentration? What is red blood protein? Is the carbon dioxide concentration the cause of alveoli's function of diffusion?" Those questions showed Jane's ability to think critically about the subject matter, a wonderful example of Translanguaging where Jane made full use of her Chinese linguistic repertoire to think and write about science. Thus, this shows the benefits of Mike's use of Translanguaging pedagogy to activate his students' dual languages and enable them to think about science using two languages.

Mike's experimentation with Translanguaging pedagogy was well received by his students. One of Mike's students reflected on his use of Chinese to learn science like this:

Before in the biology class, I often felt guilty of speaking too much Chinese in class discussions, a reminder of my poor English. But there are so many new English words in biology. I follow the translated word glossary given by the teacher and look into the dictionary for the additional new words, while copying down the notes from the board and textbook. Because of all this, I couldn't participate or think 
about those words. Now Mr. Chen lets us use Chinese if we can express our ideas more clearly and gives us time to remember what we learned back in China about this topic both before and during the lesson, and that really helped me a lot.

Semester long discussions, readings, and teaching using Culturally and linguistic and Translanguaging pedagogy led Mike, along with other bilingual subject matter teachers, to grapple with their dual role of bilingual language teacher and subject matter teacher and challenges placed by the school administration and constrains set by the bilingual program. Soon Mike began to question the goal of the TBE program in his school and its effectiveness. Mike reflected on all this as below:

\section{Mike's Reflection}

This semester, through the cross-cultural education study it brought to my attention that I cannot neglect the importance of my bilingual ELLs' previous language and literacy learning history built in schools in China. I need to bridge two languages and two literacy learning histories together in order to teach biology effectively.

Before, I was so concerned about whether I have met with the required language percentages given by the administration, such as using $80 \%$ of students' native language and $20 \%$ of English at the beginning of the year and transitioning into using $80 \%$ of English and $20 \%$ of students' native language at the end of the year. Now I see that those arbitrary requirements lose sight of who the students are and what they bring to the class.

Translanguaging pedagogy opens up my teaching possibilities and especially helps with my concept-based and inquiry-oriented discussions to avoid the pitfalls of turning the biology class into learning from word glossaries and translations. I learned so much about what my Chinese bilingual students know, including what they already learned about biology in their home countries. l'll keep making those connections in my biology classes. In doing so, my students will find motivation and purpose in what we learn. As a result, the discussion can be more inquiry and meaning based as well as conceptual language oriented.

\section{Conclusion}

This study examined Mike's, innovative ways of using culturally and linguistic responsive approach and Translanguaging pedagogy to teach science to his Chinese bilingual students. Mike was a high school biology teacher. He started out with an investigation into his bilingual students' native language and literacy and science learning experiences in China to inform him of what and how to use what his students bring to his classroom to learn biology. Armed with that knowledge, Mike created time and space for students to think back to what they have learned and use those links purposefully and critically during the class discussion. Those opportunities that Mike created enabled his students to add to scientific inquiry, express their intelligence, and achieve conceptual understanding.
This also allowed the students to wrestle through challenging reading and scientific concepts and push the discussion to a deeper level. Mike's teaching shows what Translanguaging pedagogy, when married to culturally and linguistically responsive pedagogy, can achieve (Lucas and Villegas, 2013).

Given students' range and level of participation as well as their reflection on the experience, it appears that all this may not be possible if Mike used English only or used the word translation alone. Research (Poza, 2015) has argued for the need to create time and space for students to foment thoughts in their full linguistic repertoire during the bilingual classroom discussion in order to develop their scientific inquiry skills and indepth understanding of key concepts (Unsal, et al. 2018). Mike's push for using analogies to increase his students' conceptual understanding as well as linguistic awareness such as the plural form of alveolus was effective that students really used their full linguistic repertoire to think and talk science. In those situations, translanguaging is more than a scaffold but a bridge to connect language and subject matter content.

As the state and college teacher preparation programs continue to seek out effective ways of preparing future bilingual teachers, it is increasingly important to examine the focuses and structures of the existing program and infuse the research-based pedagogies to facilitate students' bilingual and biliteracy skills and subject matter learning. As shown in Mike's reflection, the "judicious use" of students' native language and rigid ways of separation between English and students' L1 mandated by the TBE program may not be effective when the goal of instruction is to learn the subject matter through language.

In addition, bilingual subject matter teachers need to be culturally and linguistic responsive while implementing Translanguaging pedagogy in the classroom. Translanguaging has to be culturally relevant and linguistic responsive. It's only when the teacher aligns language instruction objectives with the subject matter instruction objectives in a culturally and linguistic responsive manner that the effect and benefits of Translanguaging can be achieved to promote students' bilingual, biliteracy learning as well as subject matter knowledge learning.

\section{References Références Referencias}

1. Aguilar, G., Uccelli, P., \& Galloway, E. P. (2020). Toward biliteracy: Unpacking the contribution of mid-adolescent dual language learners' Spanish and English academic language skills to English reading comprehension. TESOL Quarterly, 54(4), 1010-1036.

2. Amaral, O. M., Garrison, L., \& Klentschy, M. (2002). Helping English learners increase achievement through inquiry-based science instruction. Bilingual Research Journal, 26(2), 213-239. 
3. Beeman, K., \& Urow, C. (2013). Teaching for biliteracy: Strengthening bridges between languages. Philadelphia, PA: Caslon Publishing.

4. Bialystok, E. (2008). Learning a second language. In A. S. Rosebery and B. Warren (Eds.). Teaching science to English language learners: Building on students' strengths. Pp. 107-118. Arlington, VA: NSTA Publishing.

5. Cho, S., \& McDonnough, J. T. (2009). Meeting the needs of high school science teachers in English language learner instruction. Journal of Science Teacher Education, 20(3), 386-402

6. Cummins, J. (2000). Language, Power, and Pedagogy: Bilingual Children in the Crossfire. UK: Multilingual Matters.

7. Cummins, J. (1979). Linguistic interdependence and the educational development of bilingual children. Review of Educational Research, 49 (2), 222-251.

8. Dong, Y. R. (2017). Tapping into English language learners' (ELLs') prior knowledge in social studies instruction. The Social Studies, 108(4), 1-9.

9. Dong, Y. R. (2013). Powerful learning tools for ELLs. The Science Teacher, 80 (4), 51-57.

10. Garcia, O., Johnson, S. I., \& Seltzer, K. (2017). The translanguaging classroom: Leveraging student bilingualism for learning. Philadelphia, PA: Caslon Publishing.

11. Garcia, O., \& Kleyn, T. (2016). Tranlanguaging with multilingual students: Learning from classroom moments. New York, NY: Routledge Taylor \& Francis Group.

12. Garcia, O., \& Li Wei. (2014). Translanguaging: Language, bilingualism and bilingual education. In. Wright, S. Boun, \& O. Garcia (Eds.), Handbook of bilingual education (pp. 223-240). Malden, MA: John Wiley.

13. Garza, E., \& Arreguin-Anderson, G. M. (2018). Translanguaging: Developing scientific inquiry in a dual language classroom. Bilingual Research Journal, $41(2), 101-116$.

14. Gay, G. (2010). Culturally responsive teaching: Theory, research, \& practice. New York, NY: Teachers College Press.

15. Hornberger, N. H., \& Link, H. (2012). Translanguaging in today's classrooms: A biliteracy lens. Theory into Practice, 51 (2), 239-247.

16. Lambert, J., \& Ariza, E. N. W. (2008). Improving achievement for linguistically and culturally diverse learners through an inquiry-based earth systems curriculum. Journal of Elementary Science Education, 20(4), 61-79.

17. Ladson-Billings, G. (1995). But that's just good teaching! The case for culturally relevant pedagogy. Theory into Practice, 34(3), 159-165.

18. Lee, O., Luykx, A., Buxton, C., \& Shaver, A. (2007). The challenge of altering elementary school teachers' beliefs and practices regarding linguistic and cultural diversity in science instruction. Journal of Research in Science Teaching, 44(9), 1269-1291.

19. Lee, O., \& Fradd, S. H. (2001). Instructional congruence to promote science learning and literacy development for linguistically diverse students. In D. R. Lavoie \& M. W. Roth (Eds.), Models for science teacher preparation: Bridging the gap between research and practice (pp. 109-126). Dordrecht: Kluwer Academic.

20. Licona, P. R., \& Kelly, G. J. (2020). Translanguaging in a middle school science classroom: Constructing scientific arguments in English and Spanish. Cultural Studies of Science Education. 15(4), 485-510.

21. Lo, C. (2020). Bilingualism and biliteracy for all: Celebrating our linguistic strengths. American Educator. 22-27.

22. Lucas, T., \& Villegas, A. M. (2013). Preparing linguistically responsive teachers: Laying the foundation preservice teacher education. Theory into Practice. 52(1), 98-109.

23. Meyers, X., \& Crawford, B. A. (2011). Teaching science as a cultural way of knowing: Merging authentic inquiry, nature of science, and multicultural strategies. Cultural Studies of Science Education, 6(5), 525-547.

24. Moore, J., \& Schleppegrell, M. (2020). A focus on disciplinary language: Bringing critical perspectives to reading and writing in science. Theory into Practice. 59(1), 99-108.

25. Morrison, J., Ardasheva, Y., Newcomer, S., Lightner, L., Ernst-Slavit, G., \& Carbonneau, K. (2020). Supporting science learning for English language learners. Journal of Educational Research and Practice, 10 (3), 254-274.

26. National Center for Education Statistics (2019). Retrieved from https://nces.ed.gov/programs/coe/ pdf/2021/cgf_508c.pdf

27. New York City Department of Education. (2021). Retrieved from https://www.schools.nyc.gov/learn ing/multilingual-learners/programs-for-english-langu age-learners

28. New York City Department of Education. (2020). English language learners and student support: School year 2018-2019 demographic report. Retrieved from https://infohub.nyced.org/docs/ default-source/default-document-library/ell-demogra phic-report.pdf.

29. New York State Department of Education (2021). Retrieved from http://www.nysed.gov/bilingual-ed/ program-options-english-language-learnersmultiling ual-learners

30. New York State (2021). NYC public schools graduation rate data. Retrieved from https://data. nysed. gov/gradrate. php?year $=2019 \&$ instid $=78896$ 78368

31. Poza, L. F. (2018). The language of ciencia: Translanguaging and learning in a bilingual science 
classroom. International Journal of Bilingual Education and Bilingualism, 21 (1), 1-19.

32. Program options for English language learners/multilingual learners. New York State Education Department. http://www.nysed.gov/biling ual-ed/program-options-english-language-learners multilingual-learners.

33. Roseberry, A. S., \& Warren, B. (2008). Teaching science to English language learners: Building on students' strengths. Eds. Alexandria, VA: NSTA.

34. Rupley. W. H., \& Slough, S. (2010). Building prior knowledge and vocabulary in science in the intermediate grade: Creating hooks for learning. Literacy Research and Instruction, 49(2), 99-112.

35. Sharon, A., Rstrepo, M. A., Lipner, M. AhituvShlomo, P., \& Altman, C. (2021). Vocabulary gains in bilingual narrative intervention. Language, Speech, and Hearing Services in Schools. 52(3), 436-448.

36. Short, D., Vogt, M. E., \& Echevarria, J. (2011). The SIOP model for teaching science to English learners. Boston, MA: Ally \& Bacon.

37. Unsal, Z., Jakobson, B. Molander, B., \& Wickman, P. (2018). Science education in a bilingual class: Problematising a translational practice. Cultural Studies of Science Education, 13(3), 317-340. 